\title{
The Labyrinth within Kafka's The Castle: A Fluctuation between Nihilism and Existentialism
}

\author{
Fatma K. El Diwany \\ ${ }^{1}$ Misr University for Science and Technology, Egypt \\ Correspondence: Fatma K. El Diwany, 10 Madkour Street, Giza, Egypt. Tel: 100-168-0504. E-mail: \\ fatmakeldiwany@gmail.com
}

Received: March 18, 2014 Accepted: May 8, 2014 Online Published: May 27, 2014

doi:10.5539/ells.v4n2p14 URL: http://dx.doi.org/10.5539/ells.v4n2p14

\begin{abstract}
Man lives within a social context he finds himself involved in. He is doomed to choose in spite of the fact that he has had no choice in his coming to the world. Man's being in the world subjects him to a series of social, political, ideological, and theological challenges that, at the end, induce a major transformation in his essence. This existentialist predicament suffered by modern man makes him stand at the brink of the precipice of nihilism where nothingness lies there enveloping many lived phenomena that may appear rationalist and meaningful. Through the characters and the technique of writing, Kafka's The Castle embodies this fluctuation between nihilism, with all its implications of the loss of meaning, and the existentialist mode of thought that tries to annihilate nothingness through social and political involvement in spite of the fact that nothingness is believed to be enveloping everything.

This paper seeks to investigate this philosophical oscillation both on the level of the text and its technique of writing and of the characters who are deeply involved within the political bureaucracy of the Castle, its ideological maze, and its theological anxiety. The spatio-temporal context $\mathrm{K}$. finds himself involved in is one which asserts one fact that has been verbalized by Nietzsche: Man would rather will nothingness than not will at all.
\end{abstract}

Keywords: Kafka, existentialism, nihilism, The Castle.

\section{Introduction}

It cannot be said that we are lacking in faith. Even the simple fact of our life is of a faith-value that can never be exhausted... One cannot not-live, after all. It is precisely in this "cannot, after all" that the mad strength of faith lies; it is in this negation that it takes on form (Blue Octavo Notebooks, Kafka).

Kafka's theological orientation is one that stands midway between nihilism and existentialism. It "revolves around a God who has either retreated or who does not exist; at the same time, it encourages faith and demands individual responsibility" (Hawkins, 2003). The dilemma central to Kafka's work is of a mind "torn between the desire to live and that of dying to life in the consuming service of his vocation: the art of literature" (Heller, 1975). This dilemma offers "wider implications touching upon a universal irresolution of the modern sensibility" (Heller, 1975).The central theme governing Kafka's work is the quest for truth undergone by his heroes; heroes stuck in a state of bewilderment resulting from their exposure to the world and its futile institutions. Kafka's heroes are positioned in a state similar to that of Plato's man whose sole perception of reality "is a play of shadows thrown on the wall of his prison" (Heller, 1975).

Kafka's problematic conceptions and philosophy have been projected in The Castle. The notion constituting the basis for Kafka's thought has mainly been the concept that "man lives... at the point of juncture between nature and spirit, and thus being situated in ambiguity, lives in a state of crisis" (Scott, 1952). In the novel the reader "is faced with the shocking spectacle of a miraculously sensitive soul incapable of being either reasonable or cynical or resigned or rebellious about the prospect of eternal damnation" (Heller, 1975). Kafka is neither an atheist denying God's presence, nor a nihilist denying any worldly values and goals. Instead, Kafka, or rather K., is "a person continually tormented between the castle up above and the powers below, a person torn between doubt and hope" (Kung, 1991). He is the modern man who is condemned to be free in a world that deprives him of the very same thing it forces on him. 


\section{Existentialism, Nihilism, and the Interstitial Space}

The term "existentialism" was first adopted by Jean-Paul Sartre, followed by his associates, especially Simone de Beauvoir, Maurice Merleau-Ponty and Albert Camus. However, Soren Kierkegaard and Martin Heidegger are mostly considered "precursors of the movement" (Crowell, 2010). Existentialism presupposes that "existence precedes essence". The major existentialist concepts can be summarized in Crowell's words:

The tension between the individual and the public; an emphasis on the worldly or "situated" character of human thought and reason; a fascination with liminal experiences of anxiety, death, the "nothing" and nihilism; the rejection of science (and above all, causal explanation) as an adequate framework for understanding human being; and the introduction of "authenticity" as the norm of self-identity, tied to the project of self-definition through freedom, choice, and commitment (2010).

Existentialist philosophers view philosophy as a way of life. According to them, philosophy is not a realm confined to specialization; on the contrary, philosophy is the way one studies life from the inside. As Kierkegaard puts it: "the fundamental truths of my existence are not representations... Rather, the truths of existence are immediately lived, felt and acted" (Bunnham, 2014). For existentialist philosophers, the term "existence" is more specifically ascribed to "man as animated by spiritual zeal" (Kuhn, 1949). This question of "existence" has been sprung out of the human encounter with "nothingness". There is no doubt that the world as well as human beings inhabiting it - do exist. However, the question is the type of this existence; whether it is an organized existence, or a haphazard one produced by mere chance. This doubt is the origin of the sense of despair which lies at the core of the existentialist thought, as put by Kuhn who argues that existentialism "is subjectivism in its passage through nihilism" (1949). Amidst this contingent encounter of existence and nonexistence, man exercises his freedom to assert his existence, since man is assumed to be existing on his own.

This concept is closely related to the concept of anxiety and authenticity. Because of his awareness of living on his own, the individual must free himself from the various modern social movements - such as utilitarianism and liberalism - that evaluate human existence and performance solely in terms of measurable outcomes. This in turn leads to the concept of freedom which extenuated in the $19^{\text {th }}$ and $20^{\text {th }}$ centuries with the rise of a secular society questioning the existing traditional values. Freedom implies complete responsibility for one's decisions and actions. That is, in the case of one's situation in this world as being on its own, both freedom and responsibility are absolute. Hence, "when I exist as an authentically free being, I assume responsibility for my whole life" (Bunnham, 2014). The mere fact of the human awareness of the absoluteness of his freedom produces anguish and anxiety because of the endless choices accompanying man's assumed freedom. In spite of the existentialist assumption that the individual freedom is absolute, it is always situated in a particular context. This situatedness and the individual's awareness of it is what renders freedom meaningful. According to Heidegger, "human existence cannot be abstracted from its world because being-in-the-world is part of the ontological structure of its existence" (Bunnham, 2014). That is, man's position in the world is inseparable from the contextual world in which he exists. Through this complicated situation, man falls a victim to endless existentialist dilemmas questioning his relation to the world, to the creator, and to his own self.

Nihilism, on the other hand, is generally associated with the condemnation of existence. The term "nihilism" is derived from the Latin word "nihil" which means "nothing". Basically, Nihilism "is a problem about humanity's relation to nature, about a crisis in human freedom and willing after the collapse of the cosmos, the erosion of a hierarchically ordered nature in which humans have a proper place." (Storey, 2011). Nihilism is thus a question of morality. The major nihilistic themes are the destruction of values, the purposelessness of the cosmic order, and epistemological failure. Nihilism is viewed by some commentators as a natural consequence of various upheavals of modernity. Others think that it "stems from human nature itself" (Storey, 2011); whereas other critics regard it as issuing "from the nature of being itself" (Storey, 2011). Nihilism, in popular culture, is mostly associated with Nietzsche who denies the presence of any order or structure in the world.

According to Nietzsche, through penetrating the social and moral facades, one discovers that "all values are baseless and that reason is impotent" (Pratt, 2014). For him, nihilism means that "the highest values devaluate themselves. The aim is lacking" (Nietzsche, 1967). In his Will to Power, Nietzsche argues for the absolute strength of nihilism and its power to expose all existing beliefs and truths:

What I relate is the history of the next two centuries. I describe what is coming, what can no longer come differently: the advent of nihilism. ... For some time now our whole European culture has been moving as toward a catastrophe, with a tortured tension that is growing from decade to decade: restlessly, violently, headlong, like a river that wants to reach the end... (Nietzsche, 1967).

In 1926, Oswald Spengler studied various cultures in his book The Decline of the West confirming that "patterns 
of nihilism were... a conspicuous feature of collapsing civilizations" (Pratt, 2014). Helmut Thielicke, to cite another example, argues that "Nihilism literally has only one truth to declare, namely, that ultimately Nothingness prevails and the world is meaningless" (Nihilism: Its Origin and Nature, with a Christian Answer, 1969). Hence, nihilism leads to the conclusion that life is amoral; all values are to be questioned, and all basic or solid beliefs are destroyed. This paper seeks to investigate, through studying The Castle, Kafka's fluctuation between these two philosophical modes of thinking, and the effect of his theological stature on the themes he explores and the techniques used to materialize these themes.

\section{Kafka between Existentialism and Nihilism}

[Kafka] goes beyond the problems of man facing his society to the problem of man facing himself and the unknown and inaccessible within him... his protagonists are seeking always not a compact with man but a compact with God ( Lerner, 1993).

Pawel describes Kafka's theological stature as a kind of a Midrash placing him in the position of a disbelieving believer. According to him, Kafka is among the "wild visionaries who found two answers for every question and four new questions for every answer in seeking to probe the ultimate riddle of God" (1992). Kafka's theology mainly revolves around the individual and the place and value of this individual in the outer world. Although, for Kafka, the self takes precedence over the other; still as in the case with other existentialists, the power of the other is sizable. In this stance, Kafka adopts the existentialist doctrine that entails the involvement of the individual within the outer world, and the outcome of this crucial interaction. This brings man to his inevitable dilemma: exercising his individual ego which entails a perennial resistance to the submission to any other force. Accordingly, if the individual sense of self is so powerful, this poses an inherent danger in ending up being "isolated and separated from the collective other" (Hawkins, 2003).

Furthermore, Kafka's theology takes us close to nihilism. If waiting and asking leads to no end, why then wait and ask? George Lukacs defines Kafka's spiritual situation as follows: "The abandonment of the world by God is evident in the incongruity of the soul and achievement. Human endeavor lacks transcendental co-ordinates" (in Stern, 1980). Kafka's effect on his contemporary readers was one of shock. Kafka's mode of writing has been referred to as the "Kafakaesque world" which "suggests the labyrinthine world in its late phase. It conjures up the world... with its absurd world wars" (Kung, 1991). Kafka's dilemma mainly sprung from the dualistic atmosphere resulting in a "spiritual antimony" intensifying his initial sense of guilt and anxiety. His unstable paternal experience laid the basis for Kafka's sense of the inevitability of "submission to the irrational and incomperehensible authority of his father" (Scott, 1952). This experience has been crucial in creating Kafka's ambivalent attitude towards all authorities; let them be social, political, or even divine. Edwin Berry Burgum reaches a gauche conclusion that kafka's "attempt to escape a dominating father left him afraid of the responsibilities of freedom in a way symbolic of the later passage of German society from the tyranny of the Empire to the Weimar Republic" (in Scott, 1952).

Writing for Kafka has been a sort of a therapeutic process aiming at projecting his dilemmas to have control over them. Like various existentialists, Kafka's way out of his dilemma was writing:

The man who can't cope with life while he is living needs one hand free to try and ward off the despair he feels at his own fate..., but with the other hand he is able to record what he sees beneath the ruins; for he sees more things than other people, and different things. He's dead in his own lifetime... and yet he is the one who really survives (Blunden, 1980).

Kafka's created personae reflect his own curse and dilemma. His heroes are quite aware of their imprisonment, but similarly "obsessed with a monomaniac desire to know" (Heller, 1975). They "find themselves further and further removed from their goals... The hero sees less; therefore he interprets instead. We as readers are totally dependent on this interpretation" (Blunden, 1980).

\section{The Castle: A Philosophical and Cognitive Labyrinth}

It has been widely claimed that $\mathrm{K}$. is a disguised portrait of Kafka and his complex philosophical and theological tendencies. He is the forty-year-old man "trying to survey a dream, a story, a recollection... The survey comes to nothing, and the novel... is the account of this failure" (Stern, 1980). Kafka can himself be the surveyor who is trying to find out answers for questions about his life, his own self, the world around him and his own essence and existence. O'Neil argues that "K's quest, and ultimately Kafka's, is an existential one, the achievement of a foundation that legitimizes one's being and that provides, like the work of a surveyor, an accurate measure of reality" (2004). However, despite Kafka's obvious assimilation of his own life experience, he has chosen to transmute his social self and "create in its place a... literary persona" (Blunden, 1980). Kafka's theological 
dilemma is projected through $\mathrm{K}$. who is portrayed as an individual torn between hope and despair, the village the world - and the transcendental truth, and between illusion and fundamental reality. K's continuous striving to reach the Castle emblematizes man's urge to hold on to transcendence amidst a world of materialism and barren bureaucracy. Also, his struggle for integration into the village community is emblematic of man's constant struggle to establish a connection to his world.

The setting of the novel is of an undeniable significance in the construction of its wider interpretation. The setting is both real and imaginary. The basis for The Castle lies in the original fragments of a "family-book" of the country-lands where the village of Osek - the residence of Kafka's ancestors - was located. This village lies 100 kilometers south of Prague and consists of two parts: the larger part is situated in a depression while the smaller one on a rise. The original description of the village provides the original layout of the novel: the lower village with its few houses leading to the village green where there is an inn. Beyond the green, the road divides. One road leads to a chapel, while the other leads to a "castle standing on the rise" (Stern, 1980). In the mid-nineteenth century, the lower village was the residence of the Jews, which formed a fairly large community. After the emancipation of the Jews, most of them retreated to the big towns. The land of the village was "entirely owned by the castle and all the peasants worked exclusively for it" (Stern, 1980). The resemblance between the fictional castle and the castle described in the family-book is openly stated:

$\mathrm{K}$. had a fleeting memory of his own home town, it was scarcely inferior to this so-called castle, if $\mathrm{K}$., had been interested only in sightseeing it would have been a waste of all the travelling, he would have done better to revisit his old home... And he drew a mental comparison between the church tower of his home town and the tower above him (The Castle, 9).

Establishing this connection is crucial since the image of the castle engraved in Kafka's inward eye has always signified the power of authorities and the reproaches of his father. The image of the Osek village forms for Kafka subsequent warnings and threats for his moral and personal development and is therefore important in studying The Castle.

The German title of the novel, Das Schloss carries a double meaning. It either means "the castle" or "the lock". That is, the protagonist seeks "what is not open to him yet persists in attempting to gain admittance" (O'Neil, 2004). As the setting of the novel is both real and imaginary, the world depicted in The Castle is both real and allegorical. It embodies what a real castle symbolizes: "power and authority; a bureaucracy drowning in a deluge of forms and files; an obscure hierarchy of officialdom making it impossible ever to find the man authorized to deal with a particular case; officials who work overtime and yet get nowhere; numberless interviews which never are to the point; inns where the peasants meet; and barmaids who serve the officials" (Heller, 1975). And at the same time, it involves man's spiritual quest in a world experiencing skepticism in the most fundamental notions. Hence, some critics render the novel a metaphor for the individual spiritual quest and hence the castle would stand for God and religion and for Kafka's theological quest; another group claims that the castle is a metaphorical representation of the government and political "labyrinthine bureaucracy" (Kuhn, 1949); whereas others view the novel as a symbol of the search for a homeland on behalf of a group of people - like Kafka himself - who have been deprived of the feeling of home and a rooted identity.

Kafka opens the novel by a description of the village reflecting the ambiguity covering the Castle, the novel, and Kafka's life as well:

The village lay deep in snow. Nothing could be seen of Castle Hill, it was wrapped in mist and darkness, not a glimmer of light hinted at the presence of the great castle" (The Castle, 3).

The village, according to Scott, is "existence, the world, in the background of which stands its general foundation, the Castle, the unconditioned, ... the Deus absconditus" (1952); between the two - the Castle and the Village - there is "so great a distance that the seeking pilgrim is brought frequently to the brink of nihilistic resignation. Yet he has a deep and finally unbreakable conviction that there is between them a secret connection the discovery of which will in effect be salvific" (Scott, 1952). K. suffers from a deeply felt need to synthesize the two realms: those of the Castle and the village; that is, the world and eternity. Furthermore, through the villagers' constant unaltered belief in the unquestionable power of the Castle, it gradually shifts from being a separate external entity into residing in their minds and marking symbolically that controlling gaze.

Any member of the village who is related - in one way or another - to the Castle is treated with equal ambiguity and respect. Klamm, K.'s direct authoritative boss, is surrounded by a vast set of officialdom and messengers that adds to the allegorical significance first implied by his assigned name. Frieda - Klamm's former mistress and K.'s present beloved - is thought of as being honored for being able to contact Klamm directly and therefore is K.'s source of achieving his goal. Barnabas - the Castle messenger assigned for K.'s correspondence affairs - 
believes that his work can play a role in regaining his family's respect and honor in the community. He also stands for K.'s only hope to get in touch with the Castle and to carry on the job assigned to him. As K. proceeds in his attempts to fulfill his goal, he gets into close contact with the village community. K. here voices Kafka's belief - which is a purely existentialist one - in the power of the community in attaining one's individuality. K. is incapable of making it alone; it is only through people that he can become successful. However, all his attempts turn futile; he is the skeptic man thrown into the skeptic world where he is left adrift, unable to connect or rather satisfy any type of authority, let it be God, the tyrannical bureaucracy or the paternal authority emblematized in the figure of the father or the head of the family.

\section{Freedom or a Will to Nothingness}

This problematic relationship with authorities troubles the achievement of absolute freedom which is a basic quality for the human experience. As discussed earlier, existentialism reflects a "process of emancipation" from all what chains human will and freedom, let them be moral and natural laws, a meaningful cosmos, or even God "whose authority would exclude every form of freedom except the one that, paradoxically, is called a perfect service" (Kuhn, 1949). Man is condemned to be free, and simultaneously chooses to be free. However, this freedom is not viewed as a privilege; on the contrary it is considered a condemnation and is a major individual crisis, since man's encounter with absolute freedom leads to his sense of despair which should be eventually conquered. The Castle evokes Kafka's perspective of a dystopian society hobbled by bureaucracy and paperwork. K.'s encounter with the bewildering bureaucracy constitutes the dystopian motif of the novel. In The Castle, as in Kafka's later novels, the reader encounters "the constantly recurring image of the immeasurably complex and altogether irrational hierarchy of officials [which] seems to exteriorize the individual's sense of bafflement before the endless elaborations of social confusion in the modern world" (Scott, 1952). The Castle stands as a metaphor for all the world forces over which we lack control, and that always inhibit our growth and freedom, and which always need to be challenged. K., eventually, is the modern individual who tries to get close to authorities (of all kinds) while pursuing his freedom. He is given fake choices in choosing his wife and a substitutional job. However, what he encounters in his quest intensifies the problematic nature of the modern man's freedom: man thinks he is free and tries to impose this freedom over the outer world; however, this freedom is still limited and is only allowed by the controlling authorities.

Kafka's created world in The Castle echoes Bentham's ideal Panopticon - prison system - which is constructed following a specific architectural model: "A central watch tower surrounded by a circular row of cells permanently exposed to the unseen Inspector in his lodge" (Corbella, 2007). It operates on the assumption that the prisoner's fear from this invisible Inspector would lead him to self-control. Hence, the novel's setting constructed as such operates on "the basis of panoptic principles, relying on an authoritarian regime and permanent surveillance for the sake of individual discipline and social stability" (Corbella, 2007). The power of the authority is symbolized through its panoptical effect: "as if the person had been alone, with no one watching him; he must be aware that he was being watched... The longer K. looked, the less he could make out, the deeper everything sank into the semi-darkness" (2007). This notion is further enhanced when K. tells Frieda: "you... see Klamm everywhere" (The Castle, 126).

Kafka's initial paternal relationship has formed the basis of his perception of and animosity towards authority. Kafka's problematic relationship with his father's authority limited his freedom. In order to feed his father's desires for him, K. had to pursue a lawyer career in an attempt to gain his father's love and approval. However, this major sacrifice added to Kafka's dilemma and to the gap between him and his father. It also led Kafka to experience the authoritative futility of modern bureaucracy. His failure to satisfy his father's aspired image, led him to feel "oppressed by his father's sheer presence" (Heller, 1975). In The Castle the reader gets in touch with various authoritative symbols of officialdom, the most important of whom is Klamm, the major symbol of the ambiguous tyrannical authority. Kafka announces through the landlady the nature of the relationship between Klamm (the representative of the authority or master) and K. (the representative of the stranger or the slave): "Listen to me, sir. Mr. Klamm is a gentleman from the castle... But what are you... You are not from the castle, you are not from the village, you are nothing" (The Castle, 44).

Another major authoritative figure is Sortini. This enigmatic character stands for the power of authorities in shaping the individuals' lives. When Sortini gets attracted to Amalia and requires her sexual submissiveness, she tries to exercise her freedom and refuses his insulting claim at the same time when her father is building hopes based on Sortini's admiration. Amalia's decision not to surrender to his whimsical demands, drifts her family directly towards the social pit. Sortini uses his authority to ostracize the family and deprive them from all social and political rights. Amalia's episode might be read as one of Kafka's anecdotes symbolizing existence and the power of authorities in chaining human freedom. Amalia stands for the individual who is asked to surrender not 
only "to the obscene claims of another finite individual, but surrender to the whole of existence in general and to its Giver - God" (Scott, 1952). This struggle between spiritual submissiveness and the natural morality is further projected through the result of Amalia's resistance for persecution. Amalia's pursue of the demands of her absolute freedom continues till the end; while her suffering family tries hard to regain the authorities' acceptance and approval, Amalia holds tight to her free choice which is the same reason of her own condemnation.

That is, the authorities entrap the characters who try to exercise their freedom, and therefore these characters neither reach their absolute freedom nor are able to deny it. The perplexity of dealing with authorities is further signaled through K.'s unsettled opinion; sometimes he marks how hard and intrigued this relation is; whereas some other times he simplifies dealing with the authorities as "extraordinarily easy" (The Castle, 53). That is, K., "contains not only the impenetrable, absurd, labyrinthine qualities of this world, but also the contradictions of human existence, anxiety, care, suffering, death, the necessity of the free, yet continually threatened and ultimately doomed by the project of life" (Kung, 1991). The first letter handled to K. by Barnabas includes the initial rules of communication:

Dear sir, as you know, you have been admitted to the count's service. Your immediate superior is the mayor of the village, who will also give you the details of your job and the terms of payment and to whom you will also be accountable... Barnabas, the bearer of this letter, will make inquiries of you from time to time in order to discover your wishes and communicate them to me (The Castle, 22).

When the mayor recalls the process through which $\mathrm{K}$. has been assigned the job and the various misunderstandings leading to the confusion, $\mathrm{k}$. comments saying: "I am entertained... in the sense that it gives me an insight into the ludicrous confusion that may possibly determine the existence of a human being" (The Castle, 57).

Kafka's presented notion of authority is tightly interwoven with his previously discussed theological philosophy:

The fact was, they were letting K., if only within the confines of the village, slip through wherever he wished, spoiling and undermining him in consequence, eliminating any kind of struggle here completely and shifting him instead into the non-official, wholly unclear, clouded, alien life-sphere... Nowhere before had $\mathrm{k}$. seen officialdom and life as interwoven as they were here, so interwoven that it sometimes even looked as if officialdom and life had changed places" (The Castle, 52-53).

That is, in the novel, as in real life, man is assumed freedom which he mistakenly takes as absolute freedom; whereas actually it is a mere free realm which is surrounded by invisible confining borders that pose limits for man's freedom. Within these confinements, man is partially free but never attains the complete or pure freedom he aspires.

\section{Man's Existentialist Dilemma}

The Castle is an embodiment of another key existentialist concept, which is estrangement, or in other words man's "encounter with the Nothingness of the world" (Kuhn, 1949). This sense of estrangement is tantamount to living in a world lacking any signs or markings. This image of an "estranged world" has long haunted contemporary existentialist literature. In Heidegger's Sein Und Zeit, man "is depicted as thrown into the world" (Kuhn, 1949). Man's guilt, according to Heidegger, is the reason behind his sense of estrangement and alienation. This sense of alienation is not confined to man's feeling of estrangement in the world; it also includes man's own self-estrangement. Kafka's own sense of alienation in the world is reflected in the portrayal of his struggling characters. This alienation is not merely a personal problem for Kafka, it is perennially the alienation of the modern man facing the modern universal context with all its ambiguity and meaninglessness. $\mathrm{K}$. is portrayed as "a stranger in the snowbound village (the world) which lies in mysterious subjection to the unapproachable lord of the Castle" (Kuhn, 1949). The protagonist's individual feeling of estrangement is also a concretization of the Jewish Diaspora. This farfetched home only exists in the mind of the estranged and forms the major part of his life quest. That is, in the novel Kafka dramatizes man's existential, political, and social estrangement in a world devoid of meaning.

K.'s quest to reach the Castle epitomizes the existentialist "illusion of a homelike world" that is incarnated in the individual's mind as a way to escape the ineluctable encounter with nothingness: death. Homelessness, according to Heidegger, is not the exceptional condition of one who has been deprived of his country or his relatives; it rather describes the fundamental aspect of the world which persists" (Kuhn, 1949). In this estranged world there is no available truth, since the "experience of estrangement involves the eclipse of faith in reason" (Kuhn, 1949):

All is imaginary - family, office, friends, the street, all imaginary, far away or close at hand...; the truth that lies closest, however, is only this, that you are beating your head against the wall of a windowless 
and doorless cell (Kafka in Heller, 1975).

The Castle has an illusory effect that hinders K.'s hold of truth:

His eyes fixed on the castle, $\mathrm{K}$. walked on, nothing else concerned him. As he came closer, however, the castle disappointed him; it really was just a wretched-looking small town, a collection of rustic hovels" (The Castle, 9).

K's belief appears from the very beginning to be based upon his fluctuation between illusion and truth, and this is Kafka's means to force the reader into accepting this paradox. This echoes the existentialist unresolved problematic relationship between the individual and the world outside his personal realm. $\mathrm{K}$. is never enabled to reach the castle:

On he went, then, but it was a long way. This road, the village high street, did not in fact lead to Castle Hill, it only went close to it but then curved away, as if on purpose, and although it took one no farther from the castle, nor did it come any nearer. K. constantly expected the road to turn in the direction of the castle at last, surely it would, and it was only because he expected it that he kept going; obviously, given his weariness, he was reluctant to leave the road... Abruptly he came to a halt and could go no further" (The Castle, 11).

On his way, K. finds himself "alone with the snow enveloping him. 'Occasion for a moment's despair,' he thought, 'if I'd been standing here purely by chance, not from choice" (The Castle, 14) to wait for Klamm; while he is waiting, he contemplates on the castle:

The castle... lay still as ever, K. had yet to see the least sign of life there, maybe it was impossible to make out anything at all from this distance, but the eyes kept wanting to, they refused to accept the stillness. Looking at the castle, $\mathrm{K}$. felt at times as if he was watching a person who was sitting there quietly, staring straight ahead (The Castle, 89).

That is, K.'s final failure to reach the castle - or rather to assert his freedom - has resulted in his feeling of anxiety and anguish. This feeling has sprung from K.'s experience with nothingness; the Castle is there and not there, Klamm is a concrete entity but at the same time inaccessible, even Frieda's love is not unconditioned. This fictional modern surveyor must abandon his belief in and hope for establishing any kind of relation with the authority. If $\mathrm{K}$. is unable to reach the Castle, and is equally unable to stop his search, then his life will resume its cyclic pattern which is man's life pattern tearing him between asserting his existence and the continuous encounter with the nihilistic nature of the world. Kafka's abandonment for The Castle before finishing it proves this very notion of K.'s, the modern man's as well as Kafka's inability to solve this dilemma.

\section{Conclusion}

The Castle is an embodiment of Kafka's theological orientation that stands midway between existentialism and nihilism. Kafka delineates in his narrative the modern man's dilemma and his philosophical fluctuation through characters stuck in a state of bewilderment and confusion. The novel touches upon various existentialist questions concerning the problematic nature of man's relation to authorities; let them be social, political or spiritual. This multilayered relationship between the characters and the bureaucratic authorities delves deep into the disputable issue of man's freedom.

Kafka is neither an atheist denying God's presence nor a nihilist who deeply questions worldly values and goals. Kafka is a modern individual constantly torn between hope and despair. Kafka's only way out of this dilemma has been the process of writing. The protagonist of The Castle is a fictional projection of Kafka's own complex philosophical and theological tendencies. He undergoes a sterile quest in which he attempts to reach a kind of connection with this world and its authorities. K., or rather Kafka, is a surveyor trying to find out answers for questions about life, his own self, the world around him, and his own essence and existence. His constant attempts and subsequent failure to reach the Castle concretize the modern man's futile struggle to reach meaning and truth in a world devoid of one and ultimate Truth.

A key question tackled by Kafka is that of freedom. Man is condemned to be free, and at the same time is deprived of absolute freedom. Man's freedom is limited through the natural laws, social and political institutions, and, above all, through God's powerful control. As existentialism seeks emancipation from all these chains that limit human will and freedom; man, according to existentialist philosophers, is doomed to pursue a process of perpetual struggle against all these authorities in order to ascertain his freedom. Through this process, man encounters nihilism and experiences nothingness which leads to his feeling of estrangement; he suffers social alienation as well as self-estrangement. The characters in the text are thus torn between their will to get engaged in worldly affairs while believing deep inside that the whole scheme of life is enveloped with nothingness. 


\section{References}

Blunden, A. (Trans.). (1980). On kafka's novels. In J. P. Stern (Ed.), The world of Franz Kafka. London: Weidenfeld and Nicolson.

Bunham, D., \& Papandreopoulos, G. (2014). Existentialism. Internet Encyclopedia of Philosophy. Retrieved from http://www.cep.utm.edu/existent/

Corbella, W. (2007). Panopticism and the construction of power in Franz Kafka's the castle. Papers on Language and Literature, 43(1). Retrieved from http://www.questia.com/read/1g1-160422638

Crowell, S. (2010). Existentialism. The stranford encyclopedia of philosophy. Retrieved from http://plato.stranford.edu/archives/win2010/entries/existentialism

Hawkins, B. (2003). Reluctant theologians: Franz Kafka, Paul Celan, Edmund Jabes. New York: Fordham University Press.

Heller, E. (1975). Franz Kafka. New York: The Viking Press.

Kafka, F. (1997). The Castle. London: Penguin Books.

Kuhn, H. (1949). Encounter with nothingness: An essay on existentialism. Hinsdale, IL: Henry Regnery.

Kung, H., \& Jens, W. (1991). Literature and religion: Pascal, Gryphius, Lessing, Holderlis Novalis, Kierkegaard, Dostoyevsky, Kafka. New York: Paragon House.

Lerner, M. (1993). Franz Kafka and the human voyage. Ideas for the ice age: Studies in a revolutionary era. New Brunswick: Transaction Publishers.

Nietzsche, F. (1967). The will to power. New York: Random House, Inc.

O’Neil, P. M. (2004). Great world writers: Twentieth century. 5. New York: Marshall Cavendish.

Pawel, E. (1992). The nightmare of reason: A life of Franz Kafka. New York: Farrar, Straus and Giroux.

Scott, N. A., Jr. (1952). Rehearsals of discomposure: Alienation and reconciliation in modern literature: Franz Kafka, Ignazio Silone, D. H. Lawrence [And] T.S. Eliot. New York: King's Crown Press.

Stern, J. P. (Ed.). (1980). The world of Franz Kafka. London: Weidenfeld and Nicolson.

Storey, D. (2011, July). Nihilism, Nature, and the Collapse of the Cosmos. Cosmos and History: The Journal of Natural and Social Philosophy, 7(2). Retrieved from http://cosmosandhistory.org/index.php/journal/article/

Thielicke, H. (1969). Nihilism: Its origins and nature with a Christian answer. New York: Schocken Books.

\section{Copyrights}

Copyright for this article is retained by the author(s), with first publication rights granted to the journal.

This is an open-access article distributed under the terms and conditions of the Creative Commons Attribution license (http://creativecommons.org/licenses/by/3.0/). 